four courses, all of which are given in the evening between seven and ten, that is, not more than three hours out of the twenty-four. In the reputable medical colleges students usually spend from eight to nine hours at the college daily, besides three or four hours in close study in their rooms ; therefore, according to Dr. Robinson's showing this institution only requires about one-quarter, certainly not more than one-third the amount of work demanded by the reputable colleges, and it still appears to us that he has not established his case against those whocall the institution, "A Diploma Mill." It is not probable that a man who has given his whole day to his trade will be able to put in three solid hours work in the evening in study; or if it be conceded that he can do this it is evident that this is very much less time than ought to be required. It is beyond our comprehension how reputable medical men can lend themselves to such an enterprise. If they wish to establish a night school in good faith they should lengthen their course to twelve years, which would give their students about the same amount of time now required in reputable colleges. INQUIRER.

\section{"Aphasia of the Hand."}

Cortland, N. Y., Dec. 1, 1896.

To the Editor:-In reference to your very interesting editorial in the last number of the Journal on "Aphasia of the Hand" will you allow me to call your attention to the opinion of Max Knies, as to the location of the lesion. You will find it at the bottom of page 92 of the German edition of "Die Beziehungen des Sehorgans und seiner Erkrankungen zu den iibrigen Krankheiten des Körpers und seiner Organe."

It is, as you will notice, that for writing, the important special center for the right hand lies about in the middle of the posterior central convolution.

$$
\text { Yours sincerely, F. W. Higgins, M.D. }
$$

\section{"God and the Doctor we Alike Adore."} Philadelphia, Dec, 2, 1896.

To the Editor:- In the Journal of November 28, a correspondent who signs himself R. M. W., inquires as to the authorship of the following lines :

"God and the doctor we alike adore,

But only when in trouble, not before.

The trouble o'er, both are alike requited :

God is forgotten, and the doctor slighted.'

I have been familiar with a similar stanza for several years and am inclined to think that the lines are incorrectly quoted by R. M. W.

In a "Code of Medical Ethics" by Jukes de Styrap, M. K. Q. C. P., etc., London, 1886, he will find the following:

"God and the doctor we alike adore

When on the brink of danger not before;

The danger past, both are alike requited;

God is forgotten and the doctor slighted!'

This does not answer your correspondent's question but it may perhaps give him a clew to its solution.

Yours truly,

Frederick P. Henry, M.D.

North East, PA., Dec. 6, 1896.

To the Editor:-The Alma Mater of Dr. Burnside Foster of St. Paul, ought to take him across her maternal knee for translating the beautiful Latin of (??) Euricius Cordus as an answer to the query of R. M. W., of Brooklyn in re the authorship of the lines "God and the doctor" et sequens. The proper although liberal translation of this quotation from $\mathrm{E}$. Cordus is I think as follows:

"Three faces wears the doctor;

When first sought an angel's;

And a God's, the cure half wrought.

But when the cure complete,

He seeks his fee,

The devil is less terrible than he."
The next time B. F. essays a translation I trust he will honor his Alma Mater better than he has with this "his maiden effort."

By the way I have often wished some enterprising firm would embellish this translation from $\mathrm{E}$. Cordus as a motto for the doctor's office. Yours truly

B. H. Putnam, M.D.

Chicago, Dec. 5, 1896.

To the Editor:-Regarding the quotation you inquire about I think that you have slightly misquoted. At the time this appeared in print, something like seven to ten years ago, I cop ied these lines, which were accredited to Texas Journal. They read as follows:

"God and the doctor we alike adore

Just on the brink of danger, not before ;

The danger passed, both are alike requited,

God is forgotten, and the doctor slighted.'

N. H. Church, M.D.

5 Blue Island A ve.

\section{NEW INSTRUMENTS.}

\section{A NEW TROCAR AND CANULA WITH SAFETY GUARD. \\ BY JOHN S MARSHALL, M.I) CHICAGO.}

This instrument was devised with a view to prevent accidents in the opening of the cavities of the antrum, the chest and cysts, hydroceles and large abscesses.

There is always danger when puncturing the antrum of Highmore, the thorax and other cavities which are filled with fluid abnormal in character and which must be evacuated of the trocar under the force sometimes necessary to puncture the tissues forming the walls of these cavities, injuring the organs contained within them, or of passing through the opposite wall and causing injuries to structures beyond.

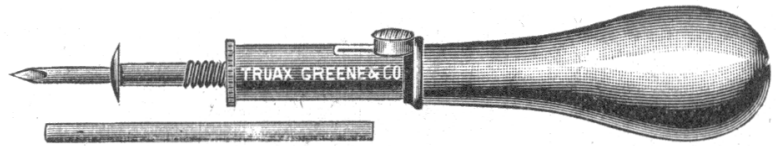

To render such accidents impossible this instrument has been fitted with a safety guard entering the handle of the instrument by means of a screw thread which makes it possible for the operator to set the guard so that the trocar and canula will enter at any depth that he may judge will be the thickness of the walls of the cavity to be punctured, without fear of injury to the important structures within or beyond. The handle also contains a device, operated by the thumb, which throws the canula forward, covering the tip of the trocar and allows the trocar to be withdrawn, leaving the canula in position. Its construction is such that the parts are easily separated and rendered aseptic by boiling.

Charles Truax, Greene \& Co. are the makers of the instrument, to whom $\mathrm{I}$ am indebted for the mechanical perfection of the idea.

36 Washington St.

\section{IMPROVED ATOMIZER.}

To throw larger quantities of the medicinal fluid on the surfaces of the lesions in nose and throat affections, Müller of Carlsbad has added to the Körting apparatus a metal spiral inside the tube. The fluid is forced through the very small bore of this spiral at a pressure of 3 to 6 atmospheres, and with an opening of $1 / 2 \mathrm{~mm}$. in diameter, a liter will be expelled in three minutes, and yet the pressure of the spray as it emerges is not strong. An olive tip excludes the air when the nose is sprayed and a bell-shaped piece answers the same purpose for the mouth. Müller has derived great benefit from 